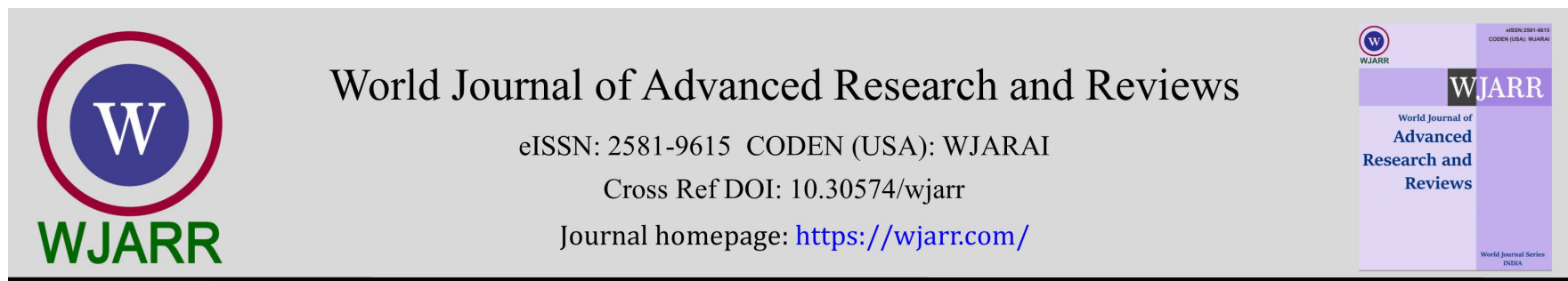

(RESEARCH ARTICLE)

Check for updates

\title{
Relationship between age and gender with cholesterol levels of Taro villagers
}

\author{
Nadya Meta Harlinda 1, Bahar Khusni 1, Reido Dafa Annafis 1, Rayhan Muhammad Basyarahil ${ }^{1}$ and Widati \\ Fatmaningrum ${ }^{2, *}$
}

${ }^{1}$ Medical Program, Faculty of Medicine, Universitas Airlangga, Surabaya, Indonesia.

2 Department of Public Health, Faculty of Medicine, Universitas Airlangga, Surabaya, Indonesia.

World Journal of Advanced Research and Reviews, 2022, 13(01), 255-260

Publication history: Received on 04 December 2021; revised on 05 January 2022; accepted on 07 January 2022

Article DOI: https://doi.org/10.30574/wjarr.2022.13.1.0010

\begin{abstract}
Introduction: COVID-19 is a disease caused by SARS-CoV-2 (Severe Acute Respiratory Coronavirus 2), an outbreak in the world in 2019 until now. High cholesterol levels correlate with increasing disease severity in SARS-CoV-2 infection because there is a surge of cases in Gianyar Regency, a district of Taro Village. This study aimed to examine the relationship between age and gender to cholesterol levels which are expected to become information for the people of Taro Village as a basis for health screening to prevent comorbid diseases that increase mortality in SARS-CoV-2 infection and increase awareness of the people of Taro Village to maintain health and implement a healthy lifestyle.
\end{abstract}

Method: Capillary blood was taken and then checked for cholesterol levels using a standardized tool on 44 respondents. The cholesterol check was conducted in Gianyar Regency, precisely in Taro Village, Tegalalang District, and Bali. The data obtained will be analyzed using univariate analysis followed by bivariate analysis using the Spearman correlation test for variables of age and cholesterol levels. In contrast, for variables gender and cholesterol levels, the Mann-Whitney test is performed.

Results: A total of 44 individual respondents in this study, the distribution of data, namely the age of the repondent is more in the $41-50$ year age group, the number of female respondents is 33 or $75.0 \%$ of the total respondent, and $70.5 \%$ of the respondent or 31 have normal cholesterol levels. The results of the Spearman test on the variables of age and cholesterol levels obtained a P value $>0,05$, and the results of the Mann Withney test on the variables gender and cholesterol levels obtained a $\mathrm{P}$ value $>0,05$.

Conclusion: Most taro villagers have normal cholesterol levels obtained as many as 31 people, or $70.5 \%$ of the total respondent. It may be influenced by the work factor of taro villagers who work a lot in the agriculture and plantation sectors. Based on the study results, there is also no significant relationship between age and gender with the cholesterol levels of Taro Villagers. However, high cholesterol levels were only found in females as many as five people.

Keywords: COVID-19; Community; Health; Cholesterol level

\section{Introduction}

COVID-19 is a disease caused by SARS-CoV-2 (Severe Acute Respiratory Coronavirus 2), an outbreak in the world in 2019. On January 30, 2020, WHO (World Health Organization) has determined that the epidemic of COVID-19 is a public health emergency of international concern (PHEIC). This virus spreads very quickly and has a high mortality rate. Patients with this viral infection will experience pneumonia, severe symptoms of acute respiratory distress syndrome (ARDS), and various organ failures [1]. In a study using a systematic review and meta-analysis method, it was found that

\footnotetext{
${ }^{*}$ Corresponding author: Widati Fatmaningrum

Department of Public Health, Faculty of Medicine, Universitas Airlangga, Surabaya, Indonesia.

Copyright (@ 2022 Author(s) retain the copyright of this article. This article is published under the terms of the Creative Commons Attribution Liscense 4.0.
} 
COVID-19 patients with pre-existing chronic or comorbid diseases had a strong correlation with an increase in disease severity [2]. Based on previous research, it was found that comorbidities in COVID-19 patients that had been sensitized were hypertension, diabetes mellitus, stroke, cancer, kidney issues, and high cholesterol levels. Hypercholesterolemia or high cholesterol levels is the beginning of atherosclerosis which is the leading cause of cardiovascular disease [3]. One of them can cause stroke, which is comorbid with COVID-19 patients. The SARS-CoV-2 virus can use serum cholesterol as a tool to enter the host so that in most studies was found that low levels of FC, HDL, and LDL cholesterol in patients with viral infections [4].

Cholesterol is a predominantly hydrophobic sterol. Cholesterol is synthesized by all cells in mammals and is primarily found in cell membranes. Cholesterol, along with lipids, plays a role in regulating the double cell membrane's rigidity, fluidity, and permeability. Besides that, cholesterol interacts with numerous other sterol transport proteins that facilitate and regulate subcellular distribution, the main organ in the biosynthesis of cholesterol in the liver. Cholesterol can be synthesized endogenously or can be obtained exogenously. Cholesterol will enter the bloodstream and turn into VLDLs (Very Low-Density Lipoproteins), after which in the bloodstream it will be processed into LDLs (Low-Density Lipoproteins), which can be taken up by peripheral cells through receptor-mediated endocytosis [5, 6, 7].

Cholesterol levels can differ according to gender and age. A study from India in 2016 found cholesterol levels in females were higher than in males after middle-age; this is in line with previous research on international data [8,9]. However, at the age of 20-55 years, males are more likely to have higher cholesterol levels than females. Based on this study, it was also found that there was a change in the increase in cholesterol levels that occurred ten years earlier [9]. Another study with cross-sectional analysis found a high variation in cholesterol levels in females and males [10]. The most commonly used for cholesterol measurement is total cholesterol, which includes LDL cholesterol and HDL cholesterol. However, because of the different effects of LDL cholesterol and HDL cholesterol in the body, it can lead to misinterpretation of the body's specific conditions for good cholesterol. Therefore, more sensitive measures, for example, the total: HDL cholesterol ratio or non-HDL cholesterol levels [11]. Cholesterol level based on Kementrian Kesehatan Republik Indonesia are divided into 3 groups: (1) normal cholesterol level ( $<200 \mathrm{mg} / \mathrm{dl}$ ), (2) high normal limit (200-239 mg/dl), and (4) high cholesterol level (>240 mg/dl) [12].

Taro Village is one of the villages in Gianyar Regency, Bali Province. Based on data from the Taro Village Government in August 2020, there were 30 cases of Covid 19 who had completed treatment and 3 cases of Covid 19 with no symptoms. The latest data from the Bali Provincial Government on July 19, 2021, obtained the number of confirmed cases of Covid 19 in Gianyar Regency, Bali, as many as 6511 people, and the death from Covid 19 as many as 150 people; this number continues to increase compared to 2020 [13, 14]. Due to an increase in cases in Gianyar Regency, which is a district of Taro Village, the researchers aimed to examine the relationship between age and gender on cholesterol levels. This study is expected to be information for the people of Taro Village as a basis for health screening to prevent comorbid diseases that increase mortality in SARS-CoV-2 infection and increase awareness of the people of Taro Village to maintain health and implement a healthy lifestyle.

\section{Material and methods}

Community service activities are designed to check cholesterol levels in Taro Village, Tegalalang District, Gianyar Regency, and Bali Province. The activity was carried out for one day on July 11,2021, with a population of 44 people who had been adjusted to the regulations for the implementation of restrictions on community activities carried out during community service activities. The independent variables were age and gender, while the dependent variable was total cholesterol levels. Community service activities are carried out by always paying attention to health protocols by maintaining distance, using masks properly, maintaining hand hygiene, using other personal protective equipment such as long-sleeved plastic aprons, latex gloves, and face shields.

Checking total cholesterol levels is done using three tools and unique standardized strips. A peripheral blood respondent was drawn from the fingertip, then dripped on a unique strip that has been attached to the tool. The results will come out in the form of numbers listed on the device's screen in a few seconds. The data obtained will be analyzed with univariate analysis to see the description of age, gender, and total cholesterol levels and then performed bivariate analysis to see whether there is a relationship between age and sex with total cholesterol levels in the Taro Village community. 


\section{Results}

\subsection{Univariate Analysis}

Based on table 1, the respondent in this study has an average age of 38.89, with the youngest respondent age being 21 years and the oldest respondent age being 53 years. Most respondents came from 41 to 50 years, as many as 17 people (38.6\%), and the minor respondent came from the age group 51-60 years, namely four people (9.1\%).

Table 1 Respondent Distribution by Age

\begin{tabular}{|l|l|c|}
\hline Age Group & n & Percentage (\%) \\
\hline 21-30 tahun & 10 & 22.7 \\
\hline $31-40$ tahun & 13 & 29.5 \\
\hline 41-50 tahun & 17 & 38.6 \\
\hline 51-60 tahun & 4 & 9.1 \\
\hline
\end{tabular}

Based on table 2, the respondent in this study was primarily female, as many as 33 people (75.0\%) out of 44 respondents, and only 11 people $(25.0 \%)$ were male in the total number of respondents.

Table 2 Respondent Distribution by Gender

\begin{tabular}{|l|l|c|}
\hline Gender & $\mathbf{n}$ & Percentage (\%) \\
\hline Female & 33 & $75.0 \%$ \\
\hline Male & 11 & $25.0 \%$ \\
\hline
\end{tabular}

Based on table 3, the respondent of this study had an average cholesterol level of $183.30 \mathrm{mg} / \mathrm{dl}$, with the lowest cholesterol level being $125 \mathrm{mg} / \mathrm{dl}$ and the highest cholesterol level being $253 \mathrm{mg} / \mathrm{dl}$. Most respondents were obtained from the group with cholesterol levels less than $200 \mathrm{mg} / \mathrm{dl}$ as many as 31 people (70.5\%), and the minor respondents came from the group with cholesterol levels more than $240 \mathrm{mg} / \mathrm{dl}$ as many as five people (11.4\%).

Table 3 Frequency Distribution of Respondents Based on Cholesterol Levels

\begin{tabular}{|l|c|c|}
\hline Cholesterol Level & $\mathbf{n}$ & Percentage (\%) \\
\hline$<200 \mathrm{mg} / \mathrm{dl}$ & 31 & $70.5 \%$ \\
\hline $200-239 \mathrm{mg} / \mathrm{dl}$ & 8 & $18.2 \%$ \\
\hline$>240 \mathrm{mg} / \mathrm{dl}$ & 5 & $11.4 \%$ \\
\hline
\end{tabular}

\subsection{Bivariate Correlation Analysis}

The relationship between age and cholesterol levels is known from the test results using the Pearson correlation test if the data has a normal distribution. If the data is not normally distributed, the test is performed using the Spearman correlation. Based on the Kolmogorov Smirnov normality test results on the variables of age and cholesterol levels, the data showed an abnormal distribution $(\mathrm{p}<0.05)$, so the relationship between age and cholesterol levels could be tested using the Spearman correlation. Based on the results of the Spearman correlation test in table 4, it was found that there was no significant correlation $(\mathrm{P}>0.05)$ between age and cholesterol levels.

The relationship between gender and cholesterol levels is known from the test results using an unpaired t-test if the data is normally distributed. If the data is not normally distributed, the Mann-Whitney test is performed. Based on the Kolmogorov Smirnov normality test results on the variable cholesterol levels in the female and male groups, the data showed that it was not normally distributed $(\mathrm{P}<0.05)$, so it would be continued with the Mann Whitney test. Based on the results of Mann Withney in table 5, it was found that there was no significant difference $(\mathrm{P}>0.05)$ of gender on cholesterol levels. 
Table 4 Spearman's Correlation Test Results Relationship between Age and Cholesterol Levels

\begin{tabular}{|c|c|c|c|c|}
\hline \multirow[b]{2}{*}{$\begin{array}{l}\text { Age } \\
\text { Group }\end{array}$} & \multicolumn{3}{|c|}{$\mathbf{n}$} & \multirow[b]{2}{*}{$\begin{array}{l}\text { Test } \\
\text { Result }\end{array}$} \\
\hline & $\begin{array}{l}\text { Cholesterol Level }(<200 \\
\mathrm{mg} / \mathrm{dl})\end{array}$ & $\begin{array}{l}\text { Cholesterol Level (200- } \\
239 \mathrm{mg} / \mathrm{dl})\end{array}$ & $\begin{array}{l}\text { Cholesterol Level (>240 } \\
\mathrm{mg} / \mathrm{dl})\end{array}$ & \\
\hline $21-30$ & 7 & 1 & 2 & \multirow{4}{*}{$\begin{array}{c}P=0.699 \\
N=44\end{array}$} \\
\hline $31-40$ & 11 & 2 & 1 & \\
\hline $41-50$ & 11 & 4 & 2 & \\
\hline $51-60$ & 2 & 1 & 0 & \\
\hline
\end{tabular}

Table 5 Mann Whitney Test Results Relationship between Gender and Cholesterol Levels

\begin{tabular}{|l|l|l|c|}
\hline Gender & Mean \pm SEM & n & p-Value \\
\hline Female & $191,52 \pm 26,759$ & 33 & \multirow{2}{*}{0.079} \\
\cline { 1 - 3 } Male & $158,64 \pm 35,367$ & 11 & \\
\hline
\end{tabular}

\section{Discussion}

\subsection{The majority of cholesterol levels in this study were found to be normal}

The study results showed that 31 people, or $70.5 \%$ of the total respondent, had normal cholesterol levels. Cholesterol levels can vary depending on our lifestyle. The AHA (American Heart Association) through cholesterol guidelines recommends four lifestyle changes in patients with hyperlipidemia: (1) eating a heart-healthy diet, (2) regular exercise, (3) avoiding tobacco smoke, and (4) losing weight in patients who have diabetes, obese or overweight [15]. This result is in line with one case report in 2017, which was found in a 33-year-old man with moderately high cholesterol levels and a family history of cardiovascular disease who was given medical intervention for six weeks in the form of changing lifestyle through diet and exercise. There was a decrease in total cholesterol and LDL cholesterol, and after six months, cholesterol levels remained constant in the normal range [16].

Demographic data of Taro Village obtained from Bappeda (Regional Development Planning Agency) and R\&D (Research and Development) of Gianyar Regency, Bali in 2021 obtained as many as $30.07 \%$ of the people, have jobs as gardeners, and $24.33 \%$ work in the rice field agriculture sector [17]. Based on research conducted in Japan, it was found that working in agriculture can reduce the risk of health care needs in old age due to a healthy diet and exercise pattern [18]. Workers in agriculture are likely to eat more vegetables than the population in general [19]. In addition, other studies have also shown that gardening activities can have a protective effect against dementia in older adults [20, 21]. The increase in total cholesterol levels has a positive relationship with dementia, specifically in AD (Alzheimer's disease), as one of the possible potential risk factors for vascular diseases in dementia [22,23]. Therefore, occupational factors that involve physical activity such as agriculture and plantations may improve health, one of which is getting more normal cholesterol levels in this study.

\subsection{There is no significant relationship between age and gender with cholesterol levels}

The study results showed that there was no significant relationship between age and gender with cholesterol levels. It means that the risk of increasing cholesterol levels can occur at all ages and genders. One of the factors that support variations in cholesterol levels is diet. A diet that can cause an increase in cholesterol levels is a western lifestyle with the consumption of Western-style fast food, which is now commonly found in the community [24]. In contrast, the diet in the vegetarian diet was found to significantly reduce HDL cholesterol, total cholesterol in females and males [25]. Another study also found that healthy dietary patterns such as consuming more fruits, milk, and vegetables have protective factors in preventing high triglycerides and HDL cholesterol levels in females [26]. However, in this study, there was no data regarding the diet of the respondent, so it cannot be known whether the influence of differences in the diet caused the cholesterol levels obtained. In addition to dietary factors, physical activity factors also increase and decrease cholesterol levels. Exercise is an activity or physical activity that can increase cholesterol metabolism. A study indicated that increased physical activity had more influence on cholesterol synthesis than weight loss and calorie restriction [27].

In this study, there was no significant relationship between gender and cholesterol levels. However, at high cholesterol levels, there was five female while none of the males had high cholesterol levels. It is appropriate because females have 
higher cholesterol levels than males [28]. There was an increase in total cholesterol in females until it reached its peak at the age of 56-57 years, while in males, it occurred at the age of 50-51 years. The average cross point of total cholesterol for female and male sex occurs at 50-51 years, namely at the median age of menopause [29]. In females, this can be caused by a drastic decrease in estrogen in the body following a drastic increase in total cholesterol [30]. However, it may be due to the weakness of the data taken from this study, namely that there are more respondents with females than males.

\section{Conclusion}

The majority of taro villagers have normal cholesterol levels obtained as many as 31 people, or $70.5 \%$ of the total respondent, have normal cholesterol levels. It may be influenced by the work factor of taro villagers who work a lot in the agriculture and plantation sectors. Based on the study results, there is also no significant relationship between age and gender with the cholesterol levels of Taro Villagers. However, high cholesterol levels were only found in females as many as five people.

\section{Compliance with ethical standards}

\section{Acknowledgments}

The authors would like to thank Taro Village's stake holders and residents and Faculty of Medicine, Universitas Airlangga, Surabaya, Indonesia for supporting this study.

\section{Disclosure of conflict of interest}

The authors declare that there are no conflict of interest that would affect the findings of this study.

\section{Statement of informed consent}

Informed consent was obtained from all participants included in this study.

\section{References}

[1] Yang, L., Liu, S., Liu, J., Zhang, Z., Wan, X., \& Huang, B. et al. COVID-19: immunopathogenesis and Immunotherapeutics. Signal Transduction And Targeted Therapy. 2020 Jul 25;5(1);128.

[2] Liu, H., Chen, S., Liu, M., Nie, H., \& Lu, H. Comorbid Chronic Diseases are Strongly Correlated with Disease Severity among COVID-19 Patients: A Systematic Review and Meta-Analysis. Aging And Disease. 2020 Jun;11(3);668.

[3] Ribeiro, S., Luz, S., \& Aquino, R. The Role of Nutrition and Physical Activity in Cholesterol and Aging. Clinics In Geriatric Medicine. 2015 May 30;31(3);401-416.

[4] Zaki, N., Alashwal, H., \& Ibrahim, S. Association of hypertension, diabetes, stroke, cancer, kidney disease, and highcholesterol with COVID-19 disease severity and fatality: A systematic review. Diabetes \& Metabolic Syndrome: Clinical Research \& Reviews. 2020 September-October;14(5);1133-1142.

[5] Luo, J., Yang, H., \& Song, B. Mechanisms and regulation of cholesterol homeostasis. Nature Reviews Molecular Cell Biology. 2020 Apr;21(4);225-245.

[6] Luo, J., Jiang, L., Yang, H., \& Song, B. Intracellular Cholesterol Transport by Sterol Transfer Proteins at Membrane Contact Sites. Trends In Biochemical Sciences. 2019 March;44(3);273-292.

[7] Wong, L., Gatta, A., \& Levine, T. Lipid transfer proteins: the lipid commute via shuttles, bridges and tubes. Nature Reviews Molecular Cell Biology. 2018 Oct 18;20(2);85-101.

[8] Carroll, M., Kit, B., Lacher, D., Shero, S., \& Mussolino, M. Trends in Lipids and Lipoproteins in US Adults, 19882010. JAMA. 2012 Oct 17;308(15);1545.

[9] Gupta, R., Sharma, M., Goyal, N., Bansal, P., Lodha, S., \& Sharma, K. Gender differences in 7 years trends in cholesterol lipoproteins and lipids in India: Insights from a hospital database. Indian Journal Of Endocrinology And Metabolism. 2016 Mar-Apr;20(2);211

[10] Tharu BP, Tsokos CP. A Statistical Study of Serum Cholesterol Level by Gender and Race. J Res Health Sci. 2017 Jul 25;17(3);e00386. 
[11] Mann, S., Beedie, C., \& Jimenez, A. Differential Effects of Aerobic Exercise, Resistance Training and Combined Exercise Modalities on Cholesterol and the Lipid Profile: Review, Synthesis and Recommendations. Sports Medicine. 2014 Feb;44(2);211-221.

[12] Kementerian Kesehatan Republik Indonesia . Nilai Normal Kolesterol Total. 2021 July 19. Available from: http://p2ptm.kemkes.go.id/

[13] Pemerintah Provinsi Bali. Update Penanggulangan Covid-19. 2021 July 19. Available from: https://infocorona.baliprov.go.id/

[14] Pemerintah Kabupaten Gianyar. Data Kasus COVID-19 di Kabupaten Gianyar Berdasarkan Desa/Kelurahan. 2021 July 19. Available from: https://covid19.gianyarkab.go.id/

[15] Okerson, T., Patel, J., DiMario, S., Burton, T., Seare, J., \& Harrison, D. Effect of 2013 ACC/AHA Blood Cholesterol Guidelines on Statin Treatment Patterns and Low-Density Lipoprotein Cholesterol in Atherosclerotic Cardiovascular Disease Patients. Journal Of The American Heart Association. 2017 Mar 17;6(3);e004909.

[16] Janse Van Rensburg, W. Lifestyle Change Alone Sufficient to Lower Cholesterol in Male Patient With Moderately Elevated Cholesterol: A Case Report. American Journal Of Lifestyle Medicine. 2018 Oct 19;13(2);148-155.

[17] Pemerintah Kabupaten Gianyar. Rencana Pembangunan Kawasan Perdesaan Wong Aga Maharsi Markandeya Desa Taro, Desa Kendran, dan Desa Tegalalang, Kecamatan Tegalalang, Kabupaten Gianyar, Provinsi Bali. 2021 July 19. Available from: https://bappeda.gianyarkab.go.id/

[18] Haruyama, K., Yokomichi, H., \& Yamagata, Z. Farm working experience could reduce late-life dependency duration among Japanese older adults. Medicine. 2020 Sep 18;99(38);e22248.

[19] Machida, D., \& Yoshida, T. Negative association of vegetable cultivation with the proportion of severely insufficient vegetable intake both directly and indirectly: A cross-sectional study in a city in Gunma, Japan. Journal Of Rural Medicine. 2018 Nov;13(2);160-167.

[20] Nakamae, T., Yotsumoto, K., Tatsumi, E., \& Hashimoto, T. Effects of Productive Activities with Reminiscence in Occupational Therapy for People with Dementia: A Pilot Randomized Controlled Study. Hong Kong Journal Of Occupational Therapy. 2014 June 1;24(1);13-19.

[21] Wang, H. Late-Life Engagement in Social and Leisure Activities Is Associated with a Decreased Risk of Dementia: A Longitudinal Study from the Kungsholmen Project. American Journal Of Epidemiology. 2002 Jun 15;155(12);1081-1087.

[22] Chen, H., Du, Y., Liu, S., Ge, B., Ji, Y., \& Huang, G. Association between serum cholesterol levels and Alzheimer's disease in China: a case-control study. International Journal Of Food Sciences And Nutrition. 2019 Jun;70(4);405411.

[23] Zhang, X., Tian, Q., Liu, D., Geng, T., Xu, X., \& Ge, S. et al. Causal association of circulating cholesterol levels with dementia: a mendelian randomization meta-analysis. Translational Psychiatry. 2020 May 12;10(1).

[24] Henry, C., Kaur, B., \& Quek, R. Are Asian foods as "fattening" as western-styled fast foods?. European Journal Of Clinical Nutrition. 2019 Nov 29;74(2);348-350.

[25] Jian, Z., Chiang, Y., Lung, C., Ho, C., Ko, P., \& Ndi Nfor, O. et al. Vegetarian diet and cholesterol and TAG levels by gender. Public Health Nutrition. 2015 Mar;18(4);721-726.

[26] Lyu, S., Su, J., Xiang, Q., \& Wu, M. Association of dietary pattern and physical activity level with triglyceride to highdensity lipoprotein cholesterol ratio among adults in Jiangsu, China: a cross-sectional study with sex-specific differences. Nutrition Research. 2014 Aug;34(8);674-681.

[27] Cho, A., Moon, J., Kim, S., An, K., Oh, M., \& Jeon, J. et al. Effects of alternate day fasting and exercise on cholesterol metabolism in overweight or obese adults: A pilot randomized controlled trial. Metabolism. 2019 Apr;93;52-60.

[28] Kim, H., Park, H., Cho, Y., Kang, J., Kim, K., \& Kang, J. et al. Gender Difference in the Level of HDL Cholesterol in Korean Adults. Korean Journal Of Family Medicine. 2011 Mar;32(3);173-181.

[29] Gold, E. The Timing of the Age at Which Natural Menopause Occurs. Obstetrics And Gynecology Clinics Of North America. 2011 Sep;38(3);425-440.

[30] Yi, S., Yi, J., \& Ohrr, H. Total cholesterol and all-cause mortality by sex and age: a prospective cohort study among 12.8 million adults. Scientific Reports. 2019 Feb 7;9(1). 